\title{
Evaluation of antipsychotic and anti-diarrhoeal activities of ethanolic extract of roots of Rubia cordifolia Linn
}

\author{
Minal T Harde, Avinash S Khairnar, Ameya S Kasture and Sanjay B Kasture* \\ NDMVP Samaj'S College of Pharmacy, Nashik 422 002, 1- AISSMS College of Pharmacy, Pune, India
}

\begin{abstract}
SUMMARY
The objective of the present study was to assess the antipsychotic and antidiarrhoeal activities of ethanolic extract of roots of Rubia cordifolia in mice and rats. The antipsychotic activity of ethanolic extract of roots of Rubia cordifolia (ERC) was evaluated by observing its effect on amphetamineinduced stereotyped behavior in mice. Effect of ERC was also studied on motor coordination and locomotion in mice. The antidiarrhoeal activity was evaluated using castor oil-induced diarrhoea and excretion of sodium and potassium ions in the intestinal secretion in rats and gastrointestinal transit in mice. The ERC inhibited amphetamine-induced stereotyped behaviour, diminished locomotion and impaired motor coordination. ERC inhibited castor oil-induced diarrhoea, decreased both sodium and potassium excretion in the intestine and decreased gastrointestinal transit. Thus the present study confirms the anti-diarrhoeal activity of Rubia cordifolia. Further studies are necessary to evaluate the potential of Rubia cordifolia as an antipsychotic.
\end{abstract}

Key words: Rubia cordifolia roots extract; Antipsychotic; Antidiarrhoeal

\section{INTRODUCTION}

Rubia cordifolia Linn (Rubiaceae) known as Manjista or Indian Madder is a climber growing in northwest Himalayas, Nilgiris, and other hilly districts of India. It is commonly used in the Indian system of Medicine for treatment of obstructions in the urinary tract, and as astringent, and diuretic. It is also useful in external inflammation, ulcers, diarrhoea, and certain skin diseases (Nadkarni, 1982). Roots of Rubia cordifolia contain anthraquinones (Wang et al., 1992), lucidin having mutagentic activity (Poginsky et al., 1983), and napthahydroquinones dimer (Itokawa et al., 1989; Itokawa and Ibraheim, 1993) having cytotoxic activity. Previous studies have reported anti-inflammatory, anticonvulsant,

*Correspondence: Sanjay B Kasture, NDMVP Samaj'S College of Pharmacy, Nashik 422 002, 1- AISSMS College of Pharmacy, Pune, India. E-mail: kasturesb@mailcity.com hypoglycemic, antistress, anxiolytic, and nootropic activities (Kasture et al., 2001, 2002; Kasture and Kasture, 2004). The ethyl acetate fraction of ethanolic extract of roots of Rubia cordifolia (ERC) has anti-oxidant and lipoxygenase-inhibiting activity (Tripathi and Sharma, 1995). The methanolic extract of Rubia cordifolia has anticancer (Advankar and Chitnis, 1982) and antiviral activity against Herpes viruses (Jin et al., 1989). The alcoholic extract also has immunomodulatory activity (Joharapurkar $e t$ al., 2003).

Rubia cordifolia contains anthraquinones. Though the anthraquinones are commonly known to cause diarrhoea (as in case of Senna leaves and Cascara bark), Rubia cordifolia is used in folklore medicine as an antidycentric. During our previous studies (Kasture et al., 2002; Kasture and Kasture, 2004) we noticed a central nervous system depressant effect of ERC. It is known that antipsychotics cause 
constipation by inhibiting cholinergic and dopaminergic transmission and also decrease gastric secretion and motility (Baldesarrini and Tarazi, 1996). Therefore in the present study we evaluated antipsychotic and antidiarrhoeal activity of ERC. ERC was given intraperitoneally for assessment of antipsychotic activity and orally for antidiarrhoeal activity.

\section{MATERIALS AND METHODS}

\section{Drugs}

d-Amphetamine (Sigma, USA), haloperidol (Searle, India), chlorpromazine (Intas, India), Analar grade polyethylene glycol-400 (PEG 400) and castor oil (Ipca, India) were used in this study. All drug solutions were prepared in distilled water immediately before experiment.

\section{Animals}

Albino Swiss mice (22 - $25 \mathrm{~g}$ ) and Wistar rats (150 $180 \mathrm{~g}$ ) of either sex were housed in groups of five under standard laboratory conditions of temperature $\left(25 \pm 2{ }^{\circ} \mathrm{C}\right)$, humidity $(55 \pm 5 \%)$, and $12 / 12 \mathrm{~h}$ light/ dark cycle. The animals had free access to standard pellets chow (Lipton, India ltd.) and distilled water. Food, but not water was deprived overnight and during the experiment. The Institutional Animal Ethical Committee approved the protocol of this study.

\section{Preparation of extract}

About $100 \mathrm{~g}$ of root powder of Rubia cordifolia was defatted with petroleum ether $\left(60-80^{\circ} \mathrm{C}\right)$ and extracted with ethanol $(90 \% \mathrm{v} / \mathrm{v})$ by cold maceration. The extract was vacuum distilled and the residue obtained was dried in air, at room temperature. The percentage yield of the ethanol was $11.50 \% \mathrm{w} / \mathrm{w}$.

\section{Pharmacological evaluation}

ERC was used for pharmacological screening. The ERC $(10-100 \mathrm{mg} / \mathrm{kg})$ was dissolved in minimum volume of polyethylene glycol-400 (PEG 400) and used for pharmacological evaluation.

\section{Behavioral study Motor coordination}

The effect of ERC on motor coordination was assessed in mice using Rotarod apparatus (INCOMedicraft, India). Mice were divided into seven groups, five in each group. The control group received vehicle (PEG 400, $10 \mathrm{ml} / \mathrm{kg}$, i.p.) and haloperidol $(1 \mathrm{mg} / \mathrm{kg}$, i.p.) whereas other groups received ERC (10, 25, 50, $100 \mathrm{mg} / \mathrm{kg}$, i.p.) with haloperidol. One group received only ERC (50 $\mathrm{mg} / \mathrm{kg}$ ). Animals were previously trained to remain on rotating rod $(20 \mathrm{rev} / \mathrm{min}$ ) for $5 \mathrm{~min}$. In order to test the motor coordination, these rats were placed individually on rotating rod and fall off time was noted as described by Dunham and Miya (1957).

\section{Spontaneous motor activity}

The effect on spontaneous motor activity was studied using Actophotometer (INCO, India) as described by Kulkarni (1989). Mice were treated with ERC (50 mg/ $\mathrm{kg}$ i.p.) or ERC $(100 \mathrm{mg} / \mathrm{kg})$ along with haloperidol $(1 \mathrm{mg} / \mathrm{kg}$ i.p.) $30 \mathrm{~min}$ before the test. The mice placed in the activity cage for $5 \mathrm{~min}$ for acclimatization and the basal activity was recorded in 5 min-observation period. The difference in activity (that is, before and after drug treatment) was noted for each dose of ERC. The effect of ERC on locomotion was compared with vehicle treated mice.

\section{Amphetamine-induced stereotypical behavior}

The mice were divided into six groups each containing five. D-amphetamine $(1 \mathrm{mg} / \mathrm{kg}$, i.p) was given $30 \mathrm{~min}$ after either the vehicle (PEG 400, $10 \mathrm{ml} / \mathrm{kg}$, i.p.) or the ERC (10 $-100 \mathrm{mg} / \mathrm{kg}$ i.p.) treatment. The mice were observed for latency to biting, grooming, rearing and repetitive head movements (RHM) as described earlier by Kandi et al. (1998). 


\section{Anti-diarrhoeal activity}

\section{Castor oil-induced diarrhoea}

Twenty four hour food deprived rats were randomly allocated to five groups of six animals each. Group I received vehicle (Distilled Water (D.W.) $10 \mathrm{ml} / \mathrm{kg}$, p.o.), group II received castor oil alone, group III received ERC alone $(100 \mathrm{mg} / \mathrm{kg}$ p.o.) while groups IV and V received ERC (50 and $100 \mathrm{mg} / \mathrm{kg}$ p.o.) respectively. Loperamide (5 mg/ $\mathrm{kg}$ p.o.) was used as a reference standard. After 60 min of these administrations, each animal was given $2 \mathrm{ml}$ of castor oil using orogastric tube and the rats were placed individually in a cage and observed for $4 \mathrm{~h}$ for percentage incidence of diarrhoea and weight of faecal matter (Awouters $e t$ al., 1978).

\section{Gastrointestinal transit}

Mice were divided into groups of six. To each animal, $1 \mathrm{ml}$ of activated charcoal meal $(12.5 \%$ charcoal plus $12.5 \%$ gum acacia in water) was given orally $60 \mathrm{~min}$ after an oral dose of vehicle or ERC. Group I was administered with vehicle (5 $\mathrm{ml} / \mathrm{kg}$ p.o.) and mice in group II and III received ERC ( 50 and $100 \mathrm{mg} / \mathrm{kg}$ p.o. respectively). After 30 min of administration of charcoal meal animals were killed by cervical dislocation and the intestine was removed without stretching and placed lengthwise on moist filter paper. The distance traveled by charcoal from pyloric sphincter to caecum was measured. The percentage of the total length traveled was evaluated for each mouse (Lutterodt, 1989).
Castor oil-induced fluid accumulation and estimation of $\mathrm{Na}^{+}$and $\mathrm{K}^{+}$secretion

The rats fasted for $24 \mathrm{~h}$ but access to water were randomized and allocated to five groups, six rats in each. Group I received vehicle (D.W. $10 \mathrm{ml} / \mathrm{kg}$, p.o.) and Group II received castor oil only (2 $\mathrm{ml}$ p.o.), group III and IV received oral administration of 50 and $100 \mathrm{mg} / \mathrm{kg}$ of ERC respectively $1 \mathrm{~h}$ prior to castor oil administration. Group $\mathrm{V}$ received loperamide $(5 \mathrm{mg} / \mathrm{kg}$, p.o.) as a standard antidiarrhoeal agent $30 \mathrm{~min}$ prior to castor oil. After $30 \mathrm{~min}$, the rats were killed by cervical dislocation and the small intestine was ligated both at pyloric sphincter and at the ileocaecal junction. The entire small intestine was dissected out, its contents were collected into a graduated measuring cylinder and the volume of the contents was recorded. The fluid samples were analyzed for $\mathrm{Na}^{+}$and $\mathrm{K}^{+}$concentrations as described earlier (Di Carlo et al., 1994) using flame photometer (Model CL 22D of Elico, India).

\section{Statistical analysis}

All observations were presented as mean \pm standard error of the mean (S.E.M.). The data were analyzed by Student's $t$ test or one-way ANOVA followed by Dunnett's test. $P<0.05$ was considered as significant.

\section{RESULTS}

\section{Effect on motor coordination}

The vehicle treated mice remained on the rotating rod for $295.25 \pm 2.02 \mathrm{~s}$. The animals remained on rotating rod for $147.0 \pm 10.5,109.0 \pm 10.0$ and $47.5 \pm$

Table 1. Effect of Rubia cordifolia on motor coordination in mice

\begin{tabular}{ccc}
\hline Group No. & Treatment (mg/kg i.p.) & Latency to fall from rotating rod (mean \pm S.E.M.) \\
\hline 1 & Vehicle & $295.25 \pm 2.02$ \\
2 & Haloperidol (1) & $169.7 \pm 2.53^{*}$ \\
3 & ERC (10) + Halo & $147.0 \pm 10.05^{*}$ \\
4 & ERC (50) + Halo & $109.0 \pm 10.0^{*}$ \\
5 & ERC (100) + Halo & $47.5 \pm 12.97^{*}$ \\
6 & ERC (50) & $200.7 \pm 26.95^{*}$ \\
\hline
\end{tabular}

$\mathrm{N}=5, \mathrm{~F}_{5,24}=38.1, P<0.001,{ }^{*} P<0.01$ compared to vehicle treated group (Dunnett's test). 


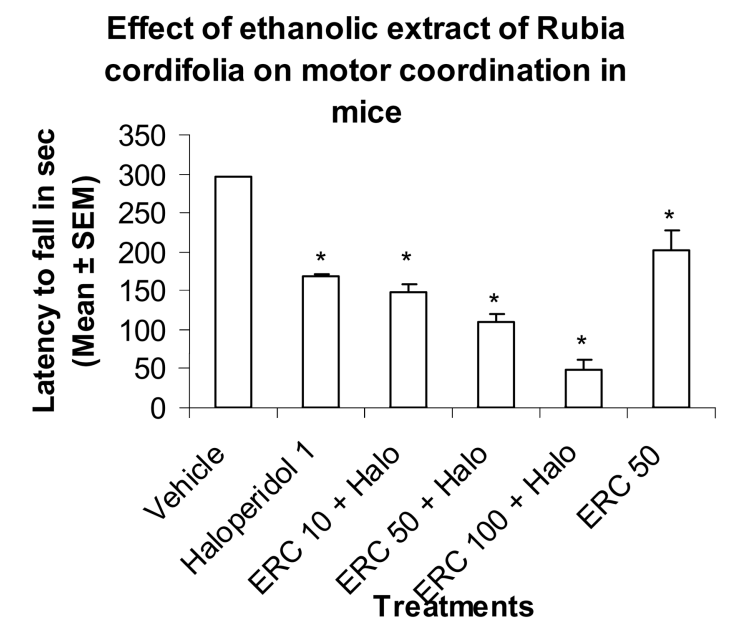

Fig. 1. Effect of ERC on motor coordination in mice. $\mathrm{N}=5, \mathrm{~F}_{5,24}=38.1, P<0.001,{ }^{*} P<0.01$, compared to the vehicle treated group (Dunnett's test).

$12.97 \mathrm{~s}$ respectively when they received ERC in doses of 10,50, $100 \mathrm{mg} / \mathrm{kg}$ along with haloperidol. The animals treated with ERC alone in a dose of $50 \mathrm{mg} / \mathrm{kg}$ stayed for $200.7 \pm 26.95 \mathrm{~s}$ while haloperidol treated mice stayed on the rotating rod for $169.7 \pm$ 2.53 s. (Table 1, Fig. 1).

\section{Locomotor activity}

The vehicle treated mice crossed the beam of light in the Actophotometer $294.0 \pm 11.37$ times during the observation period of $5 \mathrm{~min}$. The ERC showed significant dose dependent reduction in locomotor activity in doses of $10,25,50,100 \mathrm{mg} / \mathrm{kg}$ given along with haloperidol $150.0 \pm 17.88,146 \pm 11.21$, $47.5 \pm 4.57$, and $40.0 \pm 6.64$ respectively. The ERC per se in a dose of $50 \mathrm{mg} / \mathrm{kg}$ reduced locomotion by $61.0 \pm 11.33$ (Table 2, Fig. 2).

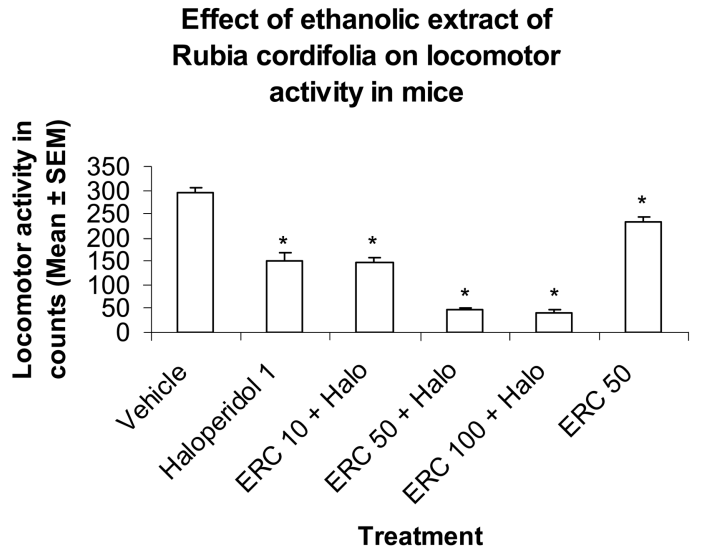

Fig. 2. Effect of ERC and haloperidol on locomotor activity in mice. $\mathrm{N}=5, \mathrm{~F}_{5,24}=78.48, P<0.0001$, ${ }^{*} P<0.01$, compared to the vehicle treated group (Dunnett's test).

\section{Amphetamine antagonism}

Following the administration of amphetamine (1 $\mathrm{mg} / \mathrm{kg}$ i.p.) all mice exhibited a stereotypical behavior (SB). After treatment with amphetamine, latencies to various SB were: biting - $3.825 \pm 0.04 \mathrm{~s}$; grooming - $131.9 \pm 12.08 \mathrm{~s}$; rearing $-11.0 \pm 1.19 \mathrm{~s}$, and RHM $-68.6 \pm 5.18$ s. Administration of ERC $(25,50$, and $100 \mathrm{mg} / \mathrm{kg})$ delayed the latency to bite, groom, rear and RHM significantly. There was no significant effect on the stereotyped behavior when ERC was administered in a dose of $10 \mathrm{mg} / \mathrm{kg}$. Haloperidol, used as a positive control inhibited amphetamine induced SB (Table 3, Fig. 3).

\section{Antidiarrhoeal activity \\ Castor oil-induced diarrhoea}

Castor oil (2 ml p.o.) produced diarrhoea in $83.3 \%$ of rats and the mean weight of feces was 1,120.25 \pm $133.5 \mathrm{mg}$. The percent incidence of diarrhoea in

Table 2. Effect of ERC on locomotor activity in mice

\begin{tabular}{ccc}
\hline Group No. & Treatment (mg/kg i.p.) & Number of counts of actophotometer (mean \pm S.E.M.) \\
\hline 1 & Vehicle & $294.0 \pm 11.37$ \\
2 & Haloperidol $(1)$ & $150.0 \pm 17.88^{*}$ \\
3 & ERC $(10)+$ Halo & $146.0 \pm 11.21^{*}$ \\
4 & ERC $(50)+$ Halo & $47.5 \pm 4.7^{*}$ \\
5 & ERC $(100)+$ Halo & $40.0 \pm 6.64^{*}$ \\
6 & ERC $(50)$ & $233.0 \pm 11.33^{*}$ \\
\hline
\end{tabular}

$\mathrm{N}=5, \mathrm{~F}_{5,24}=78.48, P<0.0001,{ }^{*} P<0.01$ compared to vehicle treated group (Dunnett's test). 
Table 3. Effect of Rubia cordifolia on amphetamine-induced stereotyped behavior in mice

\begin{tabular}{|c|c|c|c|c|c|}
\hline \multirow{2}{*}{ Group No. } & \multirow{2}{*}{$\begin{array}{c}\text { Treatment } \\
(\mathrm{mg} / \mathrm{kg})\end{array}$} & \multicolumn{4}{|c|}{ Latency in second (mean \pm S.E.M.) to } \\
\hline & & Biting & Grooming & Rearing & Repetitive Head movements \\
\hline 1 & Vehicle & $3.8 \pm 0.04$ & $131.9 \pm 12.08$ & $11.0 \pm 1.97$ & $68.6 \pm 5.18$ \\
\hline 2 & ERC (10) & $4.62 \pm 0.2$ & $168.2 \pm 21.11$ & $13.33 \pm 1.72$ & $85.4 \pm 4.41$ \\
\hline 3 & ERC (25) & $17.2 \pm 0.14^{*}$ & $205.0 \pm 22.2^{*}$ & $87.0 \pm 11.4^{*}$ & $112.0 \pm 11.23$ \\
\hline 4 & ERC (50) & $18.8 \pm 0.96^{*}$ & $221.0 \pm 19.1^{*}$ & $198.0 \pm 17.2^{*}$ & $129.0 \pm 21.23^{*}$ \\
\hline 5 & ERC (100) & $19.7 \pm 1.61^{*}$ & $239.0 \pm 13.1^{*}$ & $241.0 \pm 21.3^{*}$ & $136.0 \pm 29.3^{*}$ \\
\hline 6 & Halo (1) & $23.2 \pm 4.28^{*}$ & $277.0 \pm 31.3^{*}$ & $287.0 \pm 23.2^{*}$ & $154.0 \pm 16.6^{*}$ \\
\hline $\mathrm{F}_{5,24}=$ & & 18.67 & 6.12 & 59.53 & 3.55 \\
\hline$P$ & & 0.0001 & 0.0001 & 0.0001 & 0.015 \\
\hline
\end{tabular}

$\mathrm{N}=5,{ }^{*} \mathrm{P}<0.001$ one way ANOVA followed by Dunnett's test. Halo: Haloperidol.

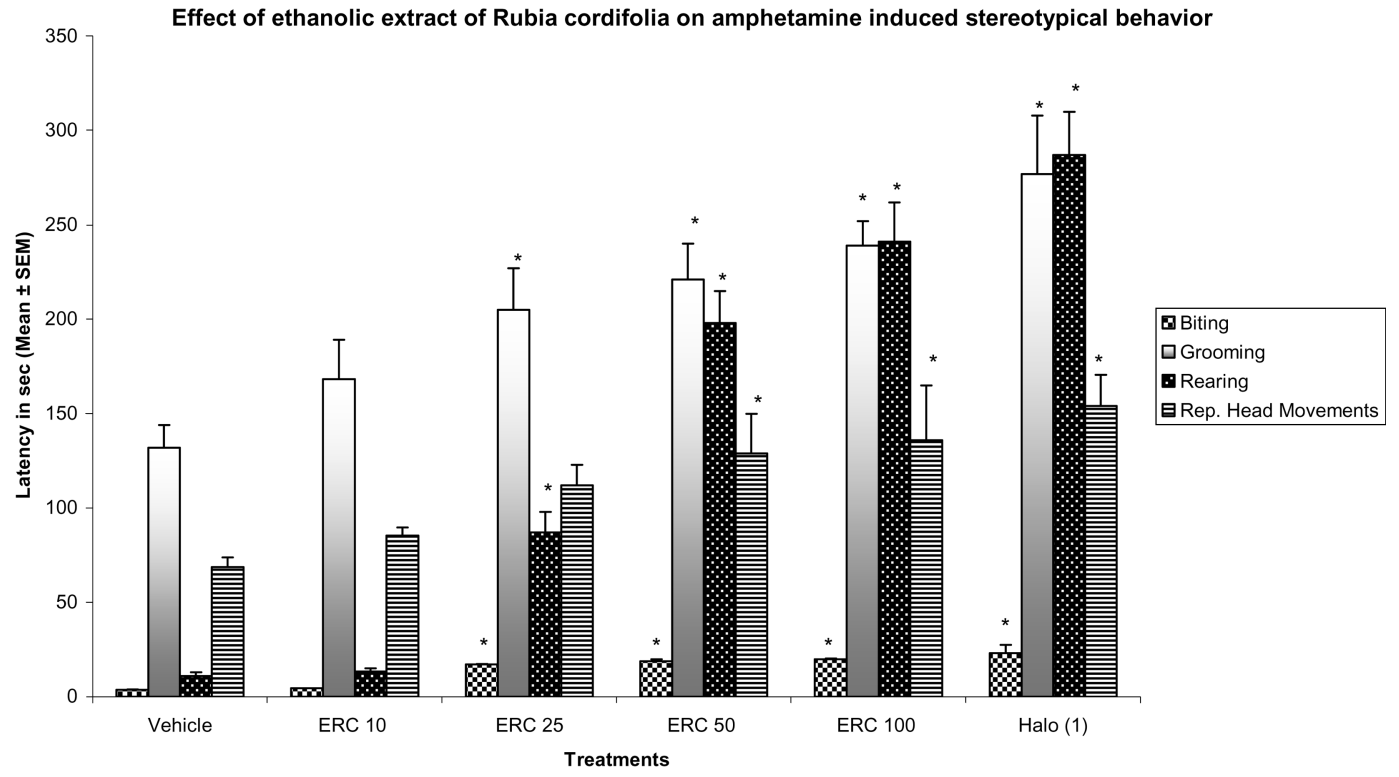

Fig. 3. Effect of ERC on amphetamine induced SB in mice. ${ }^{*} P<0.01$, compared to the vehicle treated group (Dunnett's test).

rats treated with ERC (50 and $100 \mathrm{mg} / \mathrm{kg}$ p. o.) and castor oil was $48.11 \%$ and $22.83 \%$ respectively. ERC also decreased the fecal weight from 1,120.25 \pm 133.25 to $864.5 \pm 55.3 \mathrm{mg}$ and $581.25 \pm 146.71 \mathrm{mg}$ respectively. Loperamide, a positive control, reduced the incidence of diarrhoea to $16.6 \%$ and the weight of stools was reduced to $401.5 \pm 51.2 \mathrm{mg}$ (35.85\% decrease as compared to castor oil treated rats) (Table 4, Fig. 4).

\section{Gastrointestinal transit}

In vehicle treated rats the extent of gastrointestinal transit after $30 \mathrm{~min}$ of administration was $72.9 \pm 11.2$ $\mathrm{cm}$. The effect of the ERC at the dose of 50 and 100 $\mathrm{mg} / \mathrm{kg}$ caused a reduction in the gastrointestinal transit to $34.24 \pm 3.02,32.48 \pm 4.17 \%$ respectively (Fig. 5).

\section{Castor oil-induced fluid accumulation and estimation of $\mathrm{Na}^{+}$and $\mathrm{K}^{+}$secretion}

The volume of intestinal fluid accumulated in the vehicle treated rats was $1.25 \pm 0.13 \mathrm{ml}$ whereas in castor oil treated group it was $3.47 \pm 0.25 \mathrm{ml}$. Treatments with ERC 50 and $100 \mathrm{mg} / \mathrm{kg}$ significantly 
Table 4. Effect of ERC on castor oil induced diarrhea

\begin{tabular}{cccc}
\hline Group No. & Treatment $(\mathrm{mg} / \mathrm{kg})$ & \% Incidence of diarrhoea & Weight of stool in mg (mean \pm S.E.M.) \\
\hline I & Vehicle & - & $651.0 \pm 135$ \\
II & Castor oil $(2 \mathrm{ml})$ & 83.3 & $1120.25 \pm 133.52^{\circledR}$ \\
III & ERC $(100)$ & - & $417.66 \pm 62.25^{*}$ \\
IV & ERC (50) + Castor oil $(2 \mathrm{ml})$ & $48.11^{\#}$ & $864.5 \pm 55.33$ \\
V & ERC $(100)+$ Castor oil $(2 \mathrm{ml})$ & $22.83^{\#}$ & $581.25 \pm 146.71^{*}$ \\
VI & Loperamide $(5)+$ Castor oil & $16.6^{\#}$ & $401.5 \pm 51.2^{*}$ \\
\hline \multicolumn{4}{c}{$\mathrm{F}_{5,30}=6.87, P=0.0001$} \\
\hline
\end{tabular}

- : Absence of Diarrhoea. $N=6,{ }^{\circledR} P<0.001$ as compared to group I, ${ }^{*} P<0.001$ as compared to group II, One Way ANOVA followed by Dunnett's test, ${ }^{\#} P<0.05$, Fisher exact test.

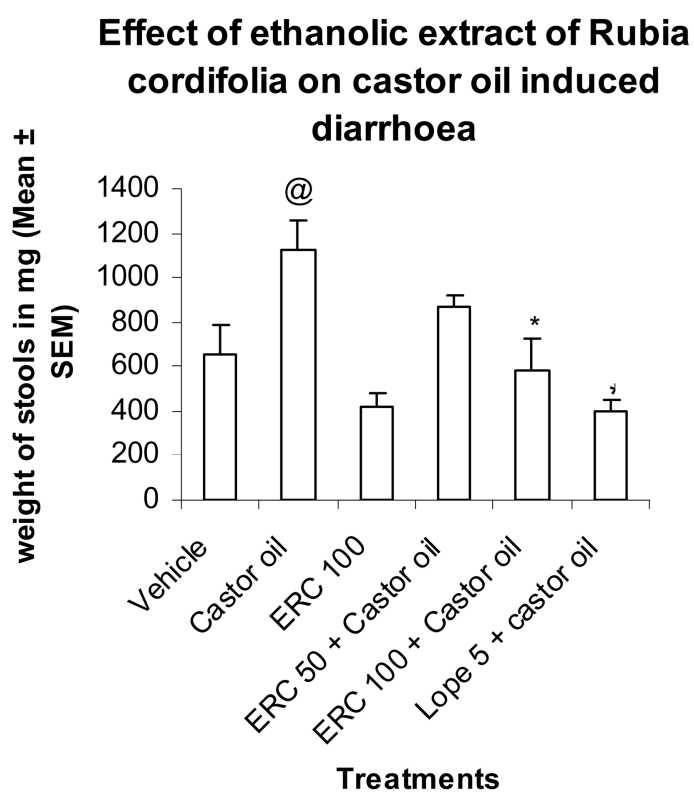

Fig. 4. Effect of ERC on castor oil induced diarrhea. @: compared to vehicle treated group. ${ }^{*} P<0.01$, compared to the castor oil treated group (Dunnett's test).

\section{Effect of ethanolic extract of Rubia cordifolia on gastrointestinal transit}

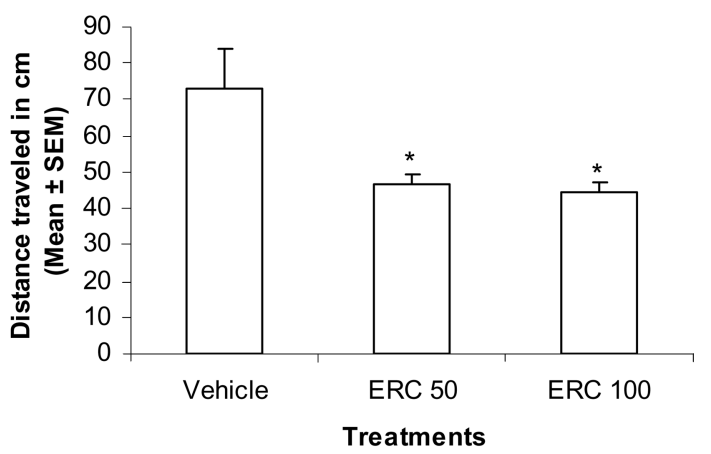

Fig. 5. Effect of ERC on gastrointestinal transit. $\mathrm{N}=6$, $\mathrm{F}_{2,15}=5.29, P<0.0182,{ }^{*} P<0.05$ compared to the castor oil treated group (Dunnett's test).

reduced the intestinal fluid volume to $2.27 \pm 0.17 \mathrm{ml}$ and $1.87 \pm 0.13 \mathrm{ml}$ respectively $(P<0.0001)$. The $\mathrm{K}^{+}$ concentration in the intestinal fluid of ERC treated

Table 5. Effect of ERC on Castor oil-induced fluid accumulation and Estimation of $\mathrm{Na}^{+}$and $\mathrm{K}^{+}$secretion

\begin{tabular}{ccccc}
\hline Sr. No. & $\begin{array}{c}\text { Treatment } \\
(\mathrm{mg} / \mathrm{kg})\end{array}$ & $\begin{array}{c}\text { Intestinal fluid in ml } \\
(\text { mean } \pm \text { S.E.M. })\end{array}$ & $\begin{array}{c}\mathrm{Na}^{+}(\mathrm{mmol} / \mathrm{l}) \\
(\mathrm{mean} \pm \text { S.E.M. })\end{array}$ & $\begin{array}{c}\mathrm{K}^{+}(\mathrm{mmol} / \mathrm{l}) \\
(\mathrm{mean} \pm \text { S.E.M. })\end{array}$ \\
\hline I & Vehicle & $1.25 \pm 0.13$ & $15.25 \pm 1.70$ & $6.4 \pm 0.78$ \\
II & Castor oil & $3.47 \pm 0.25^{\#}$ & $39.25 \pm 3.32^{\#}$ & $10.836 \pm 1.14^{\#}$ \\
III & CPZ (2) + CO & $1.92 \pm 0.13^{*}$ & $17.55 \pm 1.78^{*}$ & $6.95 \pm 0.5^{*}$ \\
IV & ERC (50) + CO & $1.87 \pm 0.13^{*}$ & $18.84 \pm 2.15^{*}$ & $6.42 \pm 0.56^{*}$ \\
V & ERC (100) + CO & $2.27 \pm 0.17^{*}$ & $22.78 \pm 2.19^{*}$ & $7.37 \pm 0.29^{*}$ \\
VI & Lope (5) + CO & $2.01 \pm 0.2^{*}$ & $19.5 \pm 1.5^{*}$ & $6.8 \pm 0.4$ \\
$F_{5,24}$ & & 15.9 & 15.84 & 6.33 \\
P & & 0.0001 & 0.0001 & 0.001 \\
\hline
\end{tabular}

$\mathrm{N}=5$, CPZ: Chlorpromazine, Lope: Loperamide, CO: Castor oil. ${ }^{\#} P<0.05$ as compared to the vehicle treated group. ${ }^{*} P<0.001$, One Way ANOVA followed by Dunnett's test, as compared to the castor oil treated group. 


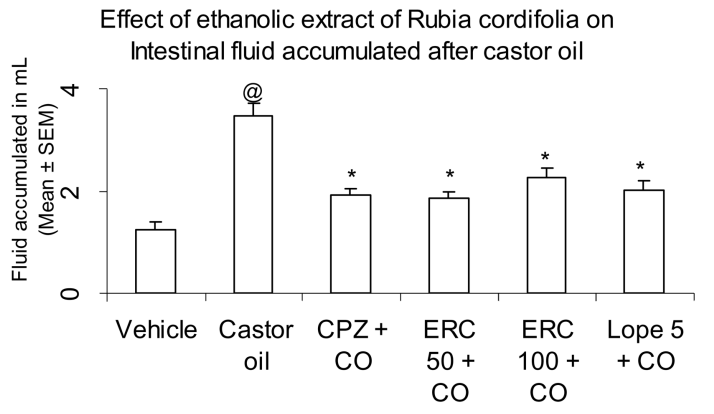

Fig. 6. Effect of ERC on intestinal fluid accumulated after castor oil. $\mathrm{N}=5, \mathrm{~F}_{5,24}=15.9, P<0.0001$, @: Compared to vehicle treated group. ${ }^{*} P<0.05$ compared to the castor oil treated group (Dunnett's test).

group was $7.37 \pm 0.29$ and $6.42 \pm 0.56 \mathrm{mmol} / \mathrm{l}$ in dose of 50 and $100 \mathrm{mg} / \mathrm{kg}$ which was significantly different from the value $10.83 \pm 1.14 \mathrm{mmol} / \mathrm{l}$ obtained from castor oil administration $(P<$ 0.0001). $\mathrm{Na}^{+}$and $\mathrm{K}^{+}$concentration in the intestinal fluid revealed that ERC had inhibitory effect on $\mathrm{Na}^{+}$and $\mathrm{K}^{+}$concentration. The administration of ERC (50 and $100 \mathrm{mg} / \mathrm{kg}$ p.o.) significantly reduced $\mathrm{Na}^{+}$concentration in castor oil-induced intestinal fluid to $22.78 \pm 0.17,18.84 \pm 2.15 \mathrm{mmol} / 1(P<$ $0.001)$. The reference standard loperamide reduced the volume of intestinal fluid, $\mathrm{Na}^{+}$and $\mathrm{K}^{+}$contents of intestinal fluid (Table 3, Fig. 6).

\section{DISCUSSION}

The results of the present study indicate that the ethanolic extract of roots of Rubia cordifolia decrease motor coordination, diminish locomotion, and inhibited amphetamine-induced SB. The extract also exhibited antidiarrhoeal activity as shown by the inhibition of castor oil-induced diarrhoea, reduced gastrointestinal transit, and decreased $\mathrm{Na}^{+}$ concentration in castor oil treated animals.

On rotating rod the ERC impaired the motor performance. It is known that weak postsynaptic dopamine DA antagonist reduces the spontaneous locomotor activity and the general depressants of nervous system decrease locomotion (Munkavad et al., 1968). The typical antipsychotic agents impair motor coordination by blockage of dopamine $\mathrm{D}_{1}$ and $\mathrm{D}_{2}$ receptors (Wang et al., 1992). The ability to block amphetamine-induced agitation is generally considered to reflect the sedative property of compound, while blockade of SB is much more specific in indicating the antipsychotic activity of the drug (Wang et al., 1992). In present study ERC antagonized the action of amphetamine by increasing latency to bite, groom, rear, and repetitive head movement.

Castor oil induced diarrhoea is characterized by semisolid droppings in all animals treated with vehicle. Ricinoleic acid of the castor oil has an irritant action on the gastrointestinal tract (Awouters et al., 1978). ERC significantly inhibited castor oil-induced diarrhoea as shown by reduction in number as well as the weight of fecal matter. ( $P$ $<0.001$ ) Treatment with the ERC produced a significant reduction in the intestinal fluid accumulation $(P<0.0001)$. ERC also reduced the gastrointestinal transit. ERC had an inhibitory effect on $\mathrm{Na}^{+}$and $\mathrm{K}^{+}$concentrations in the intestinal fluid after administration of castor oil. Castor oil increases the peristaltic activity and produces changes in the intestinal mucosal membrane permeability to electrolyte and water (Di Carlo et al., 1994). Membrane bound enzyme $\mathrm{Na}^{+}$and $\mathrm{K}^{+}-$ ATPase has been related to $\mathrm{Na}^{+}$and $\mathrm{K}^{+}$transport in the intestine. It is known that synthetic antipsychotics cause constipation by reducing cholinergic and dopaminergic transmission (Baldesarrini and Tarazi, 1996), however antidycentric drugs do not show antipsychotic activity. This study has shown that Rubia cordifolia has both antipsychotic and antidiarrhoeal activities. Further studies are necessary to isolate the active ingredient responsible for these activities and to find out the adverse effects which are related to antipsychotics and antidiarrhoeal agents.

\section{REFERENCES}

Advankar MK, Chitnis MP. (1982) In-Vitro anticancer 
activity of RC-18. Chemotherapy 28, 291-296.

Awouters F, Niemegeers CJE, Lanaerts FM, Janssen PA J. (1978) Delay of castor oil-induced diarrhoea in rats: a new way to evaluate the prostaglandin synthesis. J. Pharm. Pharmacol. 30, 41-45.

Baldesarrini RJ, Tarazi FI. (1996) Drugs and the treatment of psychiatric disorders: Psychosis and Mania. In: Goodman Gilman's The Pharmacological Basis of Therapeutics. Eds. Hardman JG, Limbird LE and Gilman AG. 10 $0^{\text {th }}$ Edn. McGraw- Hill, New Delhi, pp. 485-520.

Di Carlo G, Mascolo N, Izzo A, Capasso F, Autore G. (1994) Effect of quercetine on gastrointestinal tract in rats and mice. Phytother. Res. 8, 42-45.

Dunham MV, Miya TS. (1957) A note on a simple apparatus for detecting neurological deficit in rats and mice. J. Am. Pharm. Assoc. 46, 208-209.

Itokawa H, Qiao Y, Shin SH. (1989) Anthraquinones and naphthohydroquinones from Rubia cordifolia. Phytochemistry 28, 3465-3468.

Itokawa H, Ibraheim ZZ. (1993) Anthraquinones, naphthohydroquinones and naphthohydroquinone dimers from Rubia cordifolia and their cytotoxic activity. Chem. Pharm. Bull. 41, 1869-1872.

Jin YH, Wang SX, La YJ. (1989) The study of antiviral effect of methanol extract of Rubia cordifolia against herpes simplex virus 2. Virol. Sinica 4, 345-349.

Joharapurkar AA, Deode NM, Zambad SP, Umathe SN. (2003) Immonomodulatory activity of alcoholic extract of Rubia cordifolia. Indian Drugs 40, 147-181.

Kandi CS, Metkar RB, Kasture SB. (1998) Effect of serotonergic agents on amphetamine-induced stereotypy. Indian J. Pharmacol. 30, 334-338.

Kasture SB, Kasture VS, Chopde CT. (2001) Anti- inflammatory activity of Rubia cordifolia roots. Indian J. Nat. Remedies 1, 111-115.

Kasture VS, Deshmukh VK, Chopde CT. (2002) Anticonvulsant and behavioral action of triterpene isolated from Rubia cordifolia Linn. Indian J. Exp. Biol. 38, 357-363.

Kasture VS, Kasture SB. (2004) Hypoglycemic, antistress, anxiolytic and nootropic activity of roots of Rubia cordifolia Linn. Orient. Pharm. Exp. Med. 4, 235-242.

Kulkarni SK. (1989) Handbook of Experimental Pharmacology. Vallabh Prakashan, Delhi, pp. 56-58.

Lutterodt GD. (1989) Inhibition of gastrointestinal release of acetylcholine by quercetine as a possible mode of action of Psidium guajava leaf extracts in the treatment of acute diarrhoeal disease. J. Ethnopharmacol. 25, 235-247.

Munkavad I, Pakenbergle R, Randrup A. (1968) Aminergic system in basal ganglia associated with stereotype behavior and catalepsy. Behav. Brain Res. 1, 89-100.

Nadkarni KM. (1982) Indian Materia Medica, $3^{\text {rd }}$ edition, Popular Prakashan, New Delhi, p. 1976.

Poginsky B, Phillips D, Westerndorf J, Blomeke B, Marquardt H. (1983) Identification of a mutagentic substances in Rubia tinctorum L. (Madder) roots. Mutat. Res. 121, 85-90.

Sheba FG, Thomas M. (2001) Study of antidiarrhoeal activity of four medicinal plants in castor oil induced diarrhoea. J. Ethnopharmacol. 76, 73-76.

Tripathi YB, Sharma M. (1995) Rubia cordifolia inhibits potato-lipoxygenases. Indian J. Exp. Biol. 33, 109-112.

Wang SX, Wu LJ, Li X, Zhu TR. (1992) Studies on anthraquinones from the roots of Rubia cordifolia. In: Yao Hsuch Pao. Acta Pharmacol. Sin. 27, 743-747. 